\title{
A linguagem mariológica de Atanásio de Alexandria
}

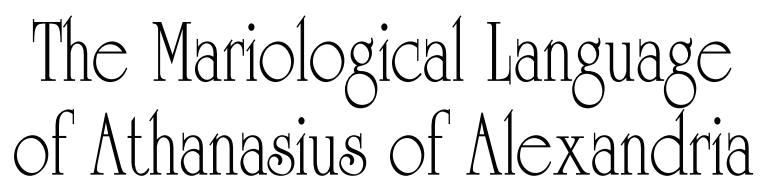

Maria Freire da Silva*

Resumo: Este artigo procura demonstrar a Linguagem mariológica no pensamento de Atanásio de Alexandria. Perceber as fontes utilizadas por Atanásio, o termo Theotókos fundamentado nos evangelhos canônicos, e os aspectos que contribuíram para apresentação da figura de Maria como modelo ascético no século IV. Enfim, como foi se configurando um retrato da Virgem como arquétipo disciplinar para os cristãos em geral, e, sobretudo para os grupos das virgens cristãs no interior do interesse e itinerário ascético atanasiano.

Palavras-chave: Maria; Ascese; Virgem; Modelo discipular.

Abstract: This article seeks to demonstrate a Mariological Language in the thought of Athanasiuns of Alexandria. It intends to realize the sources used by Athanasius, the term Theotokos that found the foundation in the canonical gospels, and the aspects that contributed to present the figure of Mary as an ascetic model in the fourth century. Finally, this article seeks to know how a portrait of the Virgin was been configured as a disciplinary archetype for

* Bacharel e Mestra em Teologia pela Pontifícia Faculdade de Teologia N. Sra. da Assunção São Paulo e Doutora em Teologia Dogmática pela Pontifícia Universidade Gregoriana, Roma, Itália. Professora da Faculdade de Teologia da Pontifícia Universidade Católica de São Paulo (PUC-SP), Contato: freiremaria3@yahoo.com.br. 
Christians in general and for the group of Christian virgins within the Athanasian interest and the ascetical itinerary.

Key words: Mary; Ascesis; Virgin; Disciple model.

\section{Introdução}

Não se pode desconsiderar o vasto patrimônio anônimo teológico, litúrgico, poético e apócrifo que foi e sempre mais se transforma em testemunho vivo da multiforme expressividade da Igreja Primitiva. 0 filão literário popular, que encontra sua máxima expressão nos séculos II e III na vasta produção dos escritos apócrifos e poéticos; traduzidas em reconfigurações artríticas, coloca em primeiro plano a figura e a vida de Maria. Também é notável a via ascética que culminará no século IV através da comunidade ascética, onde Maria se apresenta como modelo e protótipo do mais perfeito seguimento de Cristo.

Desde o II e III séculos do cristianismo, o termo exemplaridade de Maria encontra eco na vida dos cristãos e, sobretudo na catequese. Encontra paralelismo antitipico na elaboração Eva-Maria elaborada a partir da antítese paulina Adão-Cristo (Rm 5,12-21), baseado em Justino mártir, em Irineu de Lião, e Tertuliano.

Tanto em Irineu como no pensamento de vários dos padres, se dá a luta no campo cristológico e soteriológico contra o dualismo gnóstico. Porém, eleva a contraposição de Justino a um nível mais forte, através da explicação da doutrina da recapitulação, anakefaláiosis, segundo a carta aos Efésios no plano teológico da economia salvífica. O pecado havia dicotomizado o ser humano, em sua relação com Deus, e a ordem da graça restabelecida a recupera para contrafazer o efeito da causa do mal. O diabo é superado pela unidade da graça. Frente à dialética dos deuses pagãos, Irineu opõe um Deus único encarnado e propõe a recapitulação redentora de Cristo. 
Desde os séculos II e III, os padres se interessam pelo tema da virgindade, no entanto, é no século IV que o mesmo ganha relevância aplicado tanto na vida cristã comunitária, como ao itinerário ascético de virgindade. Aí se encontra o pensamento de Atanásio de Alexandria a esse respeito, onde a exemplaridade de Maria como espelho de autêntica virgindade ganha uma vestimenta ascética e espiritual.

\section{A linguagem mariológica no pensamento de Atanásio de Alexandria (295-373)}

\subsection{Atanásio e a Controvérsia Arianista}

Falar sobre a linguagem Mariológica, no pensamento de Atanásio de Alexandria, exige o mínimo de contextualização sobre esse personagem enérgico, inteligente, versátil na arte da interpretação da palavra de Deus e na ascese cristã. Doutor da Igreja, foi bispo em Alexandria, sofrendo vários exílios. Autor de obras apologéticas e dogmáticas. Foi polêmico com clareza de ideias e eficácia em exprimi-las. Sua obra sobre Antônio foi determinante para difusão do movimento monástico egípcio no Ocidente. Alexandria era há muito tempo um centro intelectual. Um sacerdote denominado Ário, homem audaz, instruído, austero e eloquente, havia iniciado uma teoria sobre o verbo divino que imediatamente provoca suspeita ao bispo Alexandre.

O arianismo sustentava que o Filho de Deus não era eterno, mas, criado do nada: por natureza não era igual a Deus, mas uma criatura. Tal teoria é levada ao Concílio de Nicéia em 325, onde Atanásio ainda diácono, participa como secretário de Alexandre, defendendo o homooúsios, a consubstancialidade do filho com o Pai. Na trilha do pensamento de Orígenes Atanásio afirma eloquentemente com clareza, que o Filho subsistia eternamente com o Pai sendo da mesma substância ou hipóstasis. ${ }^{1}$

ATANASIO. Il credo di Niceia. introduzione,Traduzione e Note a cura di E. Cattaneo. Roma: Città Nuova, 2001. p. 30. 
A encarnação supõe superação da corrupção da humanidade e a restauração da pessoa humana em seu estado original. Atanásio defende o sentido da encarnação, morte e ressurreição. Dessa forma defende com precisão a doutrina da redenção.

É notável que a vida e obra de Atanásio estão interligadas à controvérsia arianista. Portanto, da mesma forma seu pensamento mariológico tem como objetivo responder a questões sobre a real maternidade de Maria e a perfeita identidade entre seu Filho e o Filho de Deus. Afronta, portanto, o discurso mariológico numa clara e precisa perspectiva teológico-salvífica. Não faltam, todavia no Tratado sobre a virgindade, que em geral a crítica não hesita em considerar autêntico, alguns elementos de desenvolvimento moral onde Maria é apresentada como modelo, sobretudo para as virgens. Aqui é fundamentalmente importante, ressaltar que Atanásio autor da Vita Antonii, intenta promover na Igreja as várias formas de vida ascética.

Do ponto de vista de PELIKAN,

No século IV, o ascetismo estava começando a se firmar na Igreja. A maior documentação encontrada sobre esse fato encontra-se na Vida de Santo Antônio, biografia de um monge cristão do deserto egípcio, escrita por Atanásio de Alexandria, onde se percebe uma vida disciplinada pela fé através da oração e do jejum com libertação da tentação do demônio travestido em forma de mulher para tentá-lo. Portanto, os apologistas do ascetismo cristão se apegaram à Virgem Maria como modelo de virgindade e autorenúncia. Atanásio vai demonstrar essa realidade em sua carta às virgens, onde apresenta Maria em uma linguagem destinada a motivar as mulheres ascetas. ${ }^{2}$

A vida de Antônio e o tratado da virgindade fazem de Atanásio um doutor do ascetismo e um mestre da perfeição cristã. Foi excelente

2 PELIKAN, J. Maria, através dos séculos, seu papel na história da cultura, São Paulo, Companhia das Letras, 2000. p. 159. Do ponto de vista de Jerônimo em 386, foi esse livro de Atanasio sobre a Vida de Antônio que motivou Marcela e outras mulheres a seguirem a vida ascética (p. 160). 
depositário da Tradição admirável interprete da Sagrada Escritura, teve um estilo rigoroso, fundado sobre os fatos e suas ideias, ausente da vã retórica e pleno de um fascínio literário. ${ }^{3}$ Sua postura teológica em defesa do credo de Nicéia teve um influxo decisivo no desenvolvimento do dogma cristão, do pensamento teológico e da espiritualidade cristã tanto no Oriente como no Ocidente. ${ }^{4}$

\subsection{A maternidade divina no pensamento de Atanásio}

Os temas fundamentais da teologia trinitária de Atanásio deriva da tradição alexandrina, porém, radicalmente reelaborada por ele sobre a base de uma exigência da unidade de Deus. Tal elaboração tem como núcleo a defesa da unidade pessoal entre a natureza divina e a humana, unidade que se realiza depois da encarnação e que se expressava em Maria mãe de Deus (Theotókos). Assim fala de uma tríplice maternidade de Maria: a) maternidade real dado que Cristo em Maria assumiu a natureza humana, virginal porque Maria se fez mãe sem contribuição humana, mas por obra do Espírito Santo, permanecendo virgem; b) a maternidade quando Jesus entrega sua mãe ao discípulo na cruz. c) a maternidade espiritual e a maternidade dos membros do corpo místico de Cristo.

O conteúdo essencial encontrado no NT e que, geralmente se entende por maternidade espiritual de Maria, com sua significação cristológica e eclesiológica correspondente a partir da realização nas e das tipologias da figura da filha de Sião, de Eva mãe dos viventes e da cidade mãe Jerusalém se supõe foi comunicado de forma oral e escrita por meio dos feitos e das palavras de Maria, relacionadas ao Senhor e ademais por sua presença histórica pós-pascal entre os discípulos a espera do Espírito prometido.

ATANASIO DI ALESSANDRIA. Vita di Antonio, Roma, Città Nuova,2015. p. 5-6.

4 BASTIAENSEN,A. A. R. "Atanasio de Alejandría," in LEONARDI, C, A, \& ZARRI,R. G.

A. in Diccionario de los santos Madrid, San Pablo,2000.p.276- 
A exemplaridade de Maria desde os primórdios da Patrística vem totalmente correlacionada à pessoa de Cristo. Desde a concepção virginal já aparece a união entre a Mãe e o Filho: Maria e Cristo. A figura de Maria emerge intimamente associada à recapitulação e à recirculação salvífica de todas as coisas em Cristo. Cristo e Maria apresentam o caminho da vida em contraposição com o da morte.

Afirma que "a Escritura que instrui e a vida de Maria, a Mãe de Deus, são suficientes como ideal de perfeição e norma de vida celeste”. Não se trata de uma justaposição: a santidade de Maria e a Palavra de Deus traduzida em vida para mostrar a beleza do itinerário espiritual que se põe em prática. SPATARO, ${ }^{5}$ citando uma frase de Francisco de Sales, diz que tem uma bela distinção entre uma partitura musical e a execução da mesma. A Bíblia é como uma partitura musical, mas, a vida de Maria é a execução perfeita e incomparável do concerto.

Atanásio recorre para falar da virgem, tanto os evangelhos canônicos quanto os apócrifos. Escreve: Maria não se alimentou por puro prazer do corpo, mas por necessidade da natureza. Do seu ponto de vista Maria sentava-se sempre com o rosto voltado para o Oriente porque rezava sempre em continuação. Deixa claro que os evangelhos canônicos dizem sobre a Virgem aquilo que é essencial. Atanásio é incansável em sua pregação mariana encorajando os fiéis a imitar a virgem, torna-se o primeiro a apresentar uma homilia sobre Maria.

Afirma que nenhum cristão pode duvidar que o Senhor nascido de Maria é Filho de Deus por substância e natureza e que ao mesmo tempo segundo as divinas escrituras é humano por natureza e o verdadeiro corpo do Senhor é verdadeiramente igual ao nosso. De fato, Maria é nossa irmã, pois todos nós somos descendentes de Abraão. Utiliza várias vezes o título de Theotókos, mais como homenagem e de devoção do que como título de relevância especificamente teológica.

SPARTARO, R. SPARTARO, R. in Studium Theologicum Salesianum/ Gerusalemme, disponível in http://www.donbosco torino.it/ita/Maria/studi/08-09/02-Verginita di Maria.html, acesso in 22//07/2017 
Essa forma de pensar encontra distinção posteriormente na elaboração mariológica dos padres capadócios que estavam relacionados com a cristandade alexandrina onde a tradição mariana era antiga e consistente, evidenciavam a maternidade divina de Maria tanto em sentido trinitário como cristológico. Basílio de Cesaréia (379) afirma que Maria é a mãe de Deus (a Theotókos), aquela que deu uma carne portadora de Deus. Jesus foi concebido no seio de Maria por intervenção do Espírito Santo, a qual se tornou mãe sem perda da virgindade. Afirma que somente Deus pode nascer de uma virgem e, essa continuar virgem. ${ }^{6}$ Gregório Nazianzeno um dos maiores teólogos da Igreja Grega recorre ao título Theotókos como de um seguro e específico critério da ortodoxia e com grande precisão expositiva, afirma que crer na divina maternidade é indispensável para se ascender à divindade.

Nazianzeno é o primeiro padre a utilizar o termo Theotókos como verdade propriamente da ortodoxia, contra Apolinário, que após utilizar o termo Theotókos negava a verdadeira maternidade divina. $\mathrm{O}$ termo será indicado cinquenta anos depois, como critério e garantia de uma reta cristologia pelo Concílio de Éfeso (431). Também afirma a virgindade no parto, e o faz apresentando-a como modelo exemplar ascético. Afirma uma prévia purificação operada pelo Espírito Santo no ato da anunciação fazendo-a capaz de conceber o Filho de Deus.

No entanto, não se pode afirmar que Nazianzeno quisesse sustentar uma preservação do pecado original, embora, em sucessivo desenvolvimento era evidente, que por amor a Cristo, Maria devia ser purificada. Apresenta um precioso testemunho sobre a fé popular no valor da intercessão de Maria. ${ }^{7}$ Apresenta Maria como protótipo e modelo de uma virgindade que é maternidade de Cristo, metáfora da

GAMBERO, L. I padri cappadoci (Basilio Magno, Gregorio Nazianzeno, Gregorio Nisseno) testimoni della tradizione mariana. Disponível em: http://www.cultura mariana. com/pdf/08-01-2011. Acesso em 23/06/2017.

7 TONIOLO, G. Testi mariani del primo millennio. Vol. 1: Padri e altri autori greci, Roma, Città Nuova, 2001.p. 333. 
fecundidade sobrenatural: dessa forma exorta a comunidade dizendo: sejamos um imitatio Virginis. ${ }^{8}$

Também em Gregório de Nissa, embora, não ofereça um tratado sobre Maria, apresenta uma mariologia rica e radicada na tradição anterior, especificamente em Irineu de Lião no que se refere ao paralelismo: Eva-Maria. O tema sobre a maternidade virginal perpassa seus escritos, onde aparece o termo Theotókos.

Utiliza o conceito Theotókos, aplicando a distinção entre Maria e as outras mulheres. Demonstra incompatibilidade entre o termo Theotókos e o termo anthropotokos. ${ }^{9}$ Do ponto de vista da compreensão do termo Anthropotokos, Maria seria apenas mãe do Homem Jesus de Nazaré.

\section{Maria, modelo ascético}

Seguindo a tradição de Orígenes que afirmava, que em Maria encontra-se um modelo autêntico, permanente e insuperável na vida cristã, Atanásio mantém o fio condutor e afirma que Maria possuía todas as qualidades. Demonstra que a mesma se orientava para o melhor de dois modos: a) lhe era prazeroso operar retamente seus deveres e se mantinha fiel e íntegra no sentido da fé e da castidade; b) Maria era totalmente centrada em Deus, sem buscar fama ou visibilidade humana alguma. Diz que assim como a mosca é fascinada pelo mel, Maria era fascinada por seus deveres, permanecendo sempre em casa sem querer ser vista em público. Era totalmente voltada para 0 serviço aos pobres, em fidelidade às Sagradas Escrituras.

Atanásio segue de forma detalhada elaborando e apresentando um rosto mariológico bastante interessante, com intento definido na catequese às mulheres, sobretudo ás virgens. Com interesse ascético, faz uma narrativa a partir de argumentos populares referentes ao

\footnotetext{
8 Ibidem, 301.

9 GIANOTTO, C. Maria, in ORIGENE, dizionario: la cultura, il pensiero, le opere, Roma, Città Nuova, 2000.p.263-266.
} 
cotidiano de Maria. Utiliza uma linguagem simples de representação e de exortação para o caminho espiritual. Tenta moldurar Maria no seu cotidiano em sua relação com Deus, projetando sua prática espiritual.

Diz que em suas orações Maria fazia os seguintes pedidos a Deus: 1) que pensamento mal nunca viesse habitar seu coração; 2) que jamais sentisse dureza de coração. 3) Jamais permitia mostrar alguma parte em nudez do seu corpo, rezava sempre pedindo pureza e capacidade para frear, a ira e os impulsos do coração. Não era dada a comentários da vida das pessoas, não gostava de ouvir críticas aos outros, tinha profundidade interior, não tinha inveja de ninguém. Não se gloriava, mas mantinha o máximo de humildade. Não se envolvia em discussões inúteis com amigos, mas, apenas argumentava quando necessário orientar alguém para o bem, para Deus. Progredia sempre na perfeição.

Ao levantar cedo, já mantinha os olhos e o coração para o Senhor, tratando de fazer o bem, não dormia muito, mas apenas o necessário para estar bem a serviço do Senhor. Não temia a morte, e rezava todos os dias para que a porta do céu lhe fosse sempre aberta. Em lugar de pão se alimentava da palavra da verdade, em vez de vinho preferia os ensinamentos do salvador. Não era uma pessoa que corria de lá para cá. Era tranquila companheira dos pais, modesta no rosto e cumpridora de seus deveres.

O objetivo da narrativa é evidente. Além de tratar dos fundamentos dos evangelhos canônicos, baseia-se, sobretudo, nos apócrifos, sobre histórias e narrativas populares, propõe às virgens e às mulheres virtuosas em geral, um retrato rico em detalhes que suscita o desejo de imitação e de estímulo ao itinerário ascético. ${ }^{10}$

O retrato apresentado de Maria tanto na sua fidelidade a Deus, como no serviço aos pobres, e no progresso da perfeição; corresponde perfeitamente à figura bíblica mariológica. Os detalhes da vida cotidiana constituem intuições do autor além da influência apócrifa. Ainda

10 DAL COVOLO, E. Maria modelo di vita in alcuni padri della Chiesa (secc II-V) Disponível em: www.culturamariana.com/.../fine16/.../Fine16-Covolo-161-180.p. 170-171. Acesso em 20 de julho de 2017. 
é de enorme relevância considerar o objetivo ascético que perpassa o período, a vida, e o pensamento atanasiano. De uma narrativa quase global fundamentada no princípio se passa lentamente a uma visão detalhada do cotidiano de Maria.

A maternidade virginal aparece como sinal da transcendência divina, o mérito é de Deus; por isso, é também sinal da única filiação divina. É uma afirmação de que Jesus tem a Deus por Pai e que Maria está ligada á encarnação. Seu pensamento mariológico se insere, sobretudo na elaboração sobre a encarnação do Verbo. O Filho de Deus adentrou ao mundo por meio do seio virginal de Maria que era livre de toda corrupção, pois a encarnação incluía a missão de uma pessoa humana para assumir a maternidade divina, e a transcendência do Menino justifica a qualidade da maternidade divina de Maria e o título de Theotókos que lhe é atribuído.

Insiste que a concepção de Jesus foi de forma miraculosa, mas, seu nascimento foi igual a de todos os homens. A virgindade emerge como condição ligada ao desenvolvimento de perfeição de Maria e como reflexo de sua santidade e de sua pureza. Sua ação se estende também às criaturas humanas. Portanto, é modelo exemplar com princípios morais: a antítese: Eva-Maria, a primeira como causadora da morte, e, a segunda como restituidora da vida. Assim, Atanásio afirma:

O Espírito Santo plasmou o corpo da virgem para oferecer a todos um pequeno sinal da sua divindade; o que significa criador de tudo. O Filho de Deus se tornou carne num corpo como o nosso, e não se limitou, o fez numa virgem pura sem mácula que não conhecia homem. Um corpo puro e não contaminado...Ele que é potente e criador do universo, preparou o corpo de uma virgem como um templo e se apropriou como um instrumento para fazer-se conhecer e nele habitar. ${ }^{11}$

O termo plasmar (plasmare) em latim significa atribuir forma, significa também modelar algo, ou alguém, o que equivale ao termo

11 ATANASIO DI ALESSANDRIA. L’incarnazionedel verbo, Roma, CittàNuova, 1993. p.52 


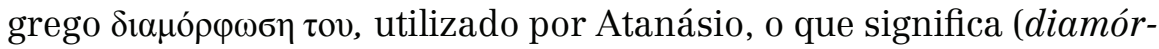
fosi tou). Também é evidente a figura de Maria como habitação do Verbo, o que pode posteriormente ser vista como ícone da encarnação. Dessa forma, compreende a virgem como templo de salvação, plasmada, modelada divinizada pelo Espírito. A cheia de graça.

Atanásio já desenvolve a questão da unidade entre as duas naturezas, humana e divina, quando diz que, como Filho de Deus, Jesus verificava o universo e não se contaminava por sua presença no corpo, mas o santificava. Não participa de todas as coisas, mas todas as coisas têm Nele vida e nutrição. ${ }^{12}$ Esse modo de pensar apresenta uma perspectiva antropológica onde o ser humano é habitação de Deus a partir de um descentrar-se de si mesmo para aí Deus habitar. ${ }^{13}$

Portanto, aquela que deseja permanecer virgem e ser esposa de Cristo, pode contemplar a vida de Maria e imitá-la pois é um programa de vida, cumprido com fidelidade e adequado ao itinerario sob o qual se configura a própria vida de virgindade.

Assim, a originalidade do pensamento atanasiano se insere especificamente no campo ascético e moral, embora predomine o interesse ascético. Ele propõe aos cristãos, e, sobretudo às virgens, como espelho e modelo de vida consagrada, a figura de Maria. O célebre retrato que faz da Virgem santa, partindo do seu cotidiano e fundamentando com os evangelhos canônicos vai encontrar relevância no mundo ocidental através da mariologia de Ambrósio de Milão. Para Ambrósio, a Virgem era:

Uma virgem pura de alma equilibrada, amava as obras boas, não desejava ser vista pelos homens, rogava a Deus constantemente, não gritava e procurava não falar mal de nada ou pessoas. Não se vangloriava, mantinha-se humilde de coração. ${ }^{14}$

\footnotetext{
12 Ibidem, p. 68.

13 PIETRO, A. “Atanasio di Alessandria” MONDIN,B. in Dizionario dei teologi, Bologna, ESD,1992. p. 73-76.

14 TONIOLO, E. "Padres de laiglesia”, in FIORES, S. \& MEO S. in Nuevodiccionario de mariologia, São Paulo, Paulinas, 1998. p.1514-1553.
} 
É possível verificar um desenvolvimento sobre a personalidade da Virgem do ponto de vista "psicológico” místico. Há um grande interesse em atribuir forma ao comportamento de Maria no intuito de formular um modelo autêntico capaz de assegurar o itinerário espiritual dos cristãos. O estilo que a ascese monástica exigia no século IV, vem carregado de sentido quando comparado ao comportamento equilibrado, puro correspondente ao recato de Maria modelo ascético original. Também é possível constar que no século IV a partir de Epifanio de Salamina, já se falava de Maria como:

Sempre virgem (azeiparzenos). O que significa que não conheceu varão nem antes (virginitas ante partum) nem durante o parto (virginitas in partu), nem depois do parto (virginitas post partum). ${ }^{15}$ Epifânio compreende Maria que era santo o corpo de Maria por ser espaço do salvador, mas, que ela não era uma divindade, mas afirma, uma santidade virginal sem defeitos. ${ }^{16}$

É evidente a preocupação catequética no uso da linguagem, como também a radicalidade na defesa da divindade de Jesus, o que supõe apresentar uma figura de Maria revestida de uma linguagem que ofereça harmoniosamente os traços que vão configurando a afirmação da maternidade divina e da santidade virginal, em vista tanto da consubstancialidade do Filho com o Pai, como também reforçar Maria como modelo para a virgindade ascética.

\section{Conclusão}

Percebe-se que os primeiros séculos do cristianismo foram importantes para a construção de um retrato da Virgem. Os padres da Igreja vão articulando elementos, alguns retirados da Sagrada escritura, outros de livros apócrifos. É evidente a presença da Tradição e do Sensus fidelium nos escritos dos padres. Dessa forma, também o

\footnotetext{
15 TORRELL, P. J. La virgen María en la fe católica, Salamanca, San Esteban, 2011, p. 79-80.

$16 \quad$ Op cit. p. 1514-1553.
} 
pensamento de Atanásio de Alexandria vem perpassado dos argumentos anteriores, II e III séculos, sobretudo no que se refere à antítese: Eva-Maria ou Maria a Nova Eva, Causa Salutis de Irineu de Lião através de seu modelo-analógico e simbólico; e das três características principais Orígenes: a Theotókos a maternidade divina, a concepção virginal; e a virgindade perpétua.

Em Orígenes é fundamental considerar o termo modelo de virgindade aplicado a Maria, como também o de exemplaridade tão caros a Atanasio que os retoma e os aprofunda como modelo para o itinerário ascético dos cristãos, e, sobretudo das virgens. O retrato que Atanásio modela após apresentar Maria a Theotókos, a Mãe de Deus, tem como objetivo formar o caráter das virgens a serviço do evangelho. Sublinha a dimensão salvífica da encarnação, e consequentemente aponta a dimensão salvífica da maternidade de Maria que dá a Cristo a carne com que nos redime. A maternidade divina é, com efeito, base indiscutível e garantia da encarnação do Filho de Deus.

A figura de Maria como modelo ascético deve espelhar a vida dos cristãos e, sobretudo das mulheres virgens. Atanásio emerge no palco do século IV, posicionando o flash frontalmente para que Maria seja toda iluminada, e assim dela possa emergir esplendidamente a LUZ, o Verbo encarnado. E que a comunidade cristã possa contemplá-la, como modelo de seguimento a Jesus Cristo. À linguagem Mariológica de Atanásio segue a trilha dos primeiros séculos realçando o colorido na tecelagem teológico-espiritual-ascética do século IV onde os grupos de virgens ganhavam espaço no mundo cristão. Vale afirmar que a Mariologia no pensamento de Atanasio está entrelaçada com sua Cristologia.

\section{Bibliografia}

ATANASIO DI ALESSANDRIA. Vita di Antonio, Roma, ed. Città Nuova,2015. . Il credo di Niceia. introduzione, Roma: ed. Città Nuova, 2001. 
. L'incarnazione del verbo, Roma, ed. Città Nuova, 1993.

BASTIAENSEN,A. A. R. "Atanasio de Alejandría," in LEONARDI, C, A, \& ZARRI,R. G. A. Diccionario de los santos, Madrid, ed. San Pablo,2000.

DAL COVOLO, E. Maria modelo di vita in alcuni padri della Chiesa (secc II-V). Disponível em: www.culturamariana.com/.../fine16/.../Fine16-Covolo-161-180. p. 170-171. Acesso em 20 de julho de 2017.

DI NOLA, G. Lo Spirito Santo nei padri, secoli I-IV, Roma, ed. Città Nuova,1999.

GAMBERO, L. I padri cappadoci (Basilio Magno, Gregorio Nazianzeno, Gregorio Nisseno) testimoni della tradizione mariana, in http://www. cultura mariana.com/pdf/08-01-2011.acesso in 23/06/2017.

. "María y la tradición”. https://udayton.edu/imri/mary/_resources/ docs-pdfs/es/maria-y-la-tradicin-patristic-01.pdf. Acesso em: 20 de julho de 2017. p. 11-12.

GIANOTTO, C. "Maria”, in CASTAGNO, A. M. in Origene dizionario, la cultura, il pensiero, le opere, Roma, ed. Città Nuova, 2000.

MORESCHINI, C. \& NORELLI. Historia de la literatura cristiana antigua griega y latina, vol. I, Madrid, ed. Biblioteca de Autores Cristianos, BAC

ORÍGENES. Contra Celso, São Paulo, ed. Paulus, 2004. p. 73-76.

ORBE, A. La teologia dei secoli II e III, il confronto della grande Chiesa con lo gnosticismo, vol. I, Roma, ed. Pontificia Università Gregoriana,1995.

PELIKAN, J. Maria, através dos séculos, seu papel na história da cultura, São Paulo, ed. Companhia das Letras,2000.

PIETRO, A. “Atanasio di Alessandria” MONDIN, B. Dizionario dei teologi, Bologna, ed. ESD,1992.

SIMONETTI, M. La crisi ariana nel IV secolo, ed. Institutum patristicum Agustinianum, Roma,1975.

SPARTARO, R. Studium Theologicum Salesianum/ Gerusalemme, disponível in http://www.donbosco torino.it/ita/Maria/studi/08-09/02-Verginita_di_Maria.html, acesso in 22//07/2017.

TONIOLO, E. "Padres de la iglesia”, in FIORES,S. \& MEO S. in Nuevo diccionario de mariologia, São Paulo, ed. Paulinas,1998. 
Revista de Cultura Teológica

Ano XXV • № 90 • Jul/Dez 2017

Testi mariani del primo millennio. Vol. 1: Padri e altri autori greci, Roma, ed. Città Nuova, 2001.

TORRELL, P, J. La virgen María en la fe católica. Salamanca, ed. San Esteban, 2011.

Recebido em: 20/08/2017

Aprovado em: 20/10/2017 